\title{
Efficiency of Buzzing Bees in Fruit Set and Seed Set of Solanum violaceum in Sri Lanka
}

\author{
R. W. M. U. M. Wanigasekara and W. A. I. P. Karunaratne \\ Department of Zoology, Faculty of Science, University of Peradeniya, Peradeniya 20400, Sri Lanka \\ Correspondence should be addressed to W. A. I. P. Karunaratne, inokap@pdn.ac.lk \\ Received 16 January 2012; Revised 3 June 2012; Accepted 12 June 2012 \\ Academic Editor: Zachary Huang
}

Copyright ( $\odot 2012$ R. W. M. U. M. Wanigasekara and W. A. I. P. Karunaratne. This is an open access article distributed under the Creative Commons Attribution License, which permits unrestricted use, distribution, and reproduction in any medium, provided the original work is properly cited.

\begin{abstract}
Plant-pollinator interactions are often considered as tightly coevolved, mutualistic relationships. The present study aimed at determining the flower visiting bees of the vegetable crop, Solanum violaceum, and the efficiency of buzz pollination by bees on fruit and seed production in Sri Lanka. Seven bee species: Hoplonomia westwoodi, Amegilla comberi, Patellapis kaluterae, Xylocopa tenuiscapa, Apis dorsata, Trigona iridipennis, and Ceratina hieroglyphica visited the flowers of S. violaceum, and the first four species were buzzing bees. Buzzing bees were the first to visit Solanum flowers and were followed by nonbuzzing bees. Handling time of $H$. westwoodi and P. kaluterae varied with the availability of pollen in anthers that deplete with the age of flower and stayed longer at new flowers than at old flowers. Handling time of the larger buzzing bee, $H$. westwoodi, was higher than that of the smaller $P$. kaluterae. The fruit set, seed set, and seed germinability in flowers visited by buzzing bees were significantly higher than those of the flowers bagged to exclude pollinators.
\end{abstract}

\section{Introduction}

Plant-pollinator interactions are very complex [1] and nearly three-quarters of Angiosperms rely on animal vectors to move pollen among flowers [2]. Colour, shape, and odour are well-known characteristics of flowers which partly determine the types of animal pollinators that visit them [3]. Unlike the majority of flowering plants in which the anthers open by splitting along the entire locule, many unrelated plants displays an unusual anther rupture mechanism in which certain anthers are poricidally dehiscent [4]. Anthers of 72 families and 574 genera of the flowering plants species dehisce via pores and of them 54 families and 357 genera restrict pollen removal by buzzing bees [5]. Pollen removal requires bees that land on the flowers [6], curl around the "anther cone" [4], and vibrate their indirect flight muscles at high frequency in contact with anthers and thereby induce rapid pollen liberation [7]. This produces an audible buzzing sound and is a unique form of pollination termed "buzz pollination" [5].

Many bees including solitary and social species, and both generalists and specialists routinely use sonication to harvest pollen [8]. Sonicating bees are found in most of the major bee families in the world, in at least seven families and over 50 genera [9]. Buchmann and Cane [8] further stated that the two genera, Apis and Trigona have never been observed to sonicate poricidal flowers. Bees belonging to the genera Hoplonomia, Lasioglossum, Patellapis (family Halictidae), and Amegilla and Xylocopa (family Apidae) have been observed to buzz at flowers with poricidal anthers in Sri Lanka [10].

Buzzing bees are usually active in early morning because anther dehiscence of most buzz flowers occurs during this period. The total time of vibration of anthers of a given flower by a buzzing bee is termed the handling time of the bee [5]. The handling time differs from one bee species to another [11]. Buchmann and Cane [8] found a positive relationship between pollen availability and handling time for individual floral visits, indicating immediate assessment of pollen returns by bees in flowers of Solanum elaeagnifolium. Furthermore, they have observed bees selectively visiting younger pollen-rich flowers than older flowers spending more time on younger flowers. Solanaceae, Melastomataceae, Bixaceae, Cochlospermaceae, Fabaceae, and Dilleniaceae are 
few examples of plant families that are pollinated by buzzing bees [12].

The dehiscence of anthers through two small apical pores is a feature found in many species of Solanaceae and especially in the genus Solanum [13]. Solanum flowers provide a relatively rich pollen source for bees that visit them [14]. Although they lack nectar and restrict access to pollen (having only terminal anther pores), they are heavily visited by a large number of individuals of at least a few species of bees [15]. Solanum is a cosmopolitan genus of more than 2000 species and is the second largest genus of flowering plants [8]. The genus Solanum is of worldwide economic importance, including major crop species such as Solanum melongena (eggplant) and S. tuberosum (potato). Even if the general syndrome of Solanum pollination is well known, there is little information $[11,16]$ about specific pollinators and pollination of Solanum species [15]. Solanum violaceum is a delicate perennial species often cultivated as an annual shrub. Solanum violaceum is considered as a wild plant in most of the world, but is a vegetable crop in Sri Lanka. However, the fruits are mostly collected from wildly grown shrubs and are very expensive in the local market. No studies have been conducted so far to identify the wild pollinators of $S$. violaceum and their importance in fruit and seed set. Therefore, the present study was designed to (i) determine the time of stigma receptivity and anther dehiscence in $S$. violaceum flowers, (ii) identify the bees that collect and carry pollen of $S$. violaceum and record their activity period, (iii) investigate the handling time of different bee species at S. violaceum flowers at different age (during peak activity period of bees), and to (iv) assess the fruit set and seed set in bagged flowers to prevent insect visits and open flowers that receive insect visitors.

\section{Materials and Methods}

The study was conducted in two sites: one located in Meewatura; Agriculture Research Field $7^{\circ} 15^{\prime} \mathrm{N}, 80^{\circ} 45^{\prime} \mathrm{E}$ ) in the Peradeniya University Park in the Kandy district and the other in a home garden $\left(7^{\circ} 15^{\prime} 11^{\prime \prime} \mathrm{N}, 80^{\circ} 21^{\prime} 2^{\prime \prime} \mathrm{E}\right)$ in the Kegalle district. Pollination trials were conducted only in the field at Kegalle where 25 seedlings were cultivated for the experiment.

\subsection{Determination of the Time of Stigma Receptivity and} Anther Dehiscence. Time of stigma receptivity and anther dehiscence was observed in freshly opened five flowers of $S$. violaceum. The time of stigma receptivity was investigated by observing the stigma through a hand lens at every 10 minutes from 6.30 a.m. to 2.00 p.m. The stigma was touched by a needle tip to observe the stickiness and was considered as the time of stigma receptivity. The time of anther dehiscence was observed by shaking the flower onto a white paper every 10 minutes from 6.30 a.m. The time at which pollen was released and collected onto the white paper was considered as the time of anther dehiscence.
2.2. Determining the Number of Pollen Grains in Anthers of Flowers at Different Age. Flowers at different age, new, 1day-old, 2-day-old and >2-day-old flowers were selected. From each flower, one anther was removed and placed in a solid watch glass. The anther was dissected longitudinally and the pollen grains were removed into the watch glass. One milliliter of $50 \%$ alcohol was added into the solid watch glass containing the pollen grains. From this mixture, $1.00 \mathrm{ml}$ volume was transferred on to a Sedgewick-Rafter Cell (a hemocytometer). Five cells with high amount of pollen grains were counted and the average number of pollen grains in the chamber was estimated. This was repeated for flowers at different age using five anthers at each age category.

\subsection{Collection and Identification of Bees Visiting S. violaceum} Flowers. Bees visiting flowers of S. violaceum were collected using a sweep net. At the Kegalle site, flower visiting bees were observed for ten sunny days until no new species were recorded. Buzzing bees were identified by the audible buzzing sound they produce at anthers during pollen gathering from anthers. Bees that do not produce an audible sound at anthers were grouped as nonbuzzing bees. Bees were collected from May 2009 at Meewature site where the preliminary survey was conducted and from August to November 2009 at Kegalle site. Bees were identified using keys to identify bees of Sri Lanka [17] and reference collection of bees lodged at the invertebrates systematics and diversity facility (ISDF) in the Department of Zoology, University of Peradeniya.

\subsection{Recording of Activity Time of Buzzing and Nonbuzzing Bees Visiting Solanum Flowers. The activity time of both buzzing and non-buzzing bee species were observed at the Kegalle site. The activity time of bees were determined by their visits to flowers between 7.00 a.m. to 4.00 p.m. on four sunny days. The abundance of each bee species was not determined.}

\subsection{Determining the Handling Time of Two Common Buzzing} Bees on Flowers at Different Age. The most common two buzzing bees that visit $S$. violaceum flowers were selected to study their handling time. Twenty flower buds ready to open were selected at the Kegalle site. The total time that a particular bee species buzzed at each of the selected flowers was recorded on 30/11/2009. On the following day, these flowers were considered 1-day old and the total handling time of each bee species at these anthers was recorded. On the third day, these flowers were considered 2-days old and the total handling time of each bee species was recorded. On the fourth day, these 20 flowers were considered $>2$-days old and the total handling time of each bee species at flowers were recorded. Accordingly, the total handling time of the two bee species on five new, 1-day-, 2-day- and $>2$-day-old flowers was observed only on sunny days (to minimize the effects from changing environmental conditions) from 30/11/2009 to $03 / 12 / 2009$ for $H$. westwoodi, and from $04 / 12 / 2009$ to 07/12/2009 for $P$. kaluterae. Ten specimens of each of the two common female (male bees do not buzz at flowers to collect pollen) buzzing bee species were measured for body length 
to investigate the difference between the body length of the two buzzing bee species.

2.6. Study of the Efficiency of Buzz Pollination by Bees for Fruit Set and Seed Set of S. violaceum. The pollination trials were conducted from August 2009 to December 2009 in the site at Kegalle to study the efficiency of buzz pollination by bees for fruit set and the seed set of S. violaceum. Fifteen bunches of flower buds were randomly selected and covered by fine mesh bags to prevent visits of bees to flowers. Another randomly selected fifteen bunches of flower buds were tagged and kept open for bees to visit. Average number of fruits produced, and the number of seeds in each fruit in the two treatments were counted. Seeds obtained from each fruit from the two treatments were counted and allowed to germinate on wet tissues in Petri dishes. The number of germinated and ungerminated seeds produced from the two treatments (bagged and open) was counted.

2.7. Data Analysis. Data obtained from the study were analyzed using Minitab 14.0 and MS Excel-2007. MS Excel2007 was used to compare the difference in the number of pollen grains in anthers of flowers at different age and the variation in handling time of the two common buzzing bee species at different age of flowers. A nonparametric test (Kruskal-Wallis test) was conducted to determine whether there is a significant relationship between the number of pollen grains per anther in flowers at different age. Twosample $t$-test was carried out using Minitab 14 to determine whether there is a significant difference between handling time of the two common buzzing bees at flowers of each age category and the difference between the body length of the two common buzzing bee species at $95 \%$ confidence interval. The same analysis was conducted to test the difference in start of activity and end of activity between the non-buzzing bees and buzzing bees on $S$. violaceum flowers. The number of fruits, seeds per fruit, and the number of germinated seeds per fruit produced from the two treatments (open and bagged flowers) were also analyzed using two-sample $t$-test.

\section{Results}

In the nursery, seedlings appeared within 20 to 30 days after planting of seeds of $S$. violaceum. Seedlings took 15 days to reach the planting stage and 120-130 days to reach the reproductive stage. Upon maturity, the plants produced flower buds within five to eight days and they developed into flowers within one week. Fruits were produced within 6570 days. On average, the plants took nearly seven months to produce mature fruits starting from the seedling stage. Flower buds took nearly one week to develop into flowers. New flowers opened around $7.30 \mathrm{a} . \mathrm{m}$. and the lifespan of a flower was three to four days. Stigma of flowers remained receptive between 8.00 and 11.30 a.m. after blooming of flowers. Anthers dehisced between 7.30 and 8.00 a.m. Pollen grains of $S$. violaceum are yellowish-white, dry, and nonsticky with $0.02 \mathrm{~mm}$ of length and breadth.

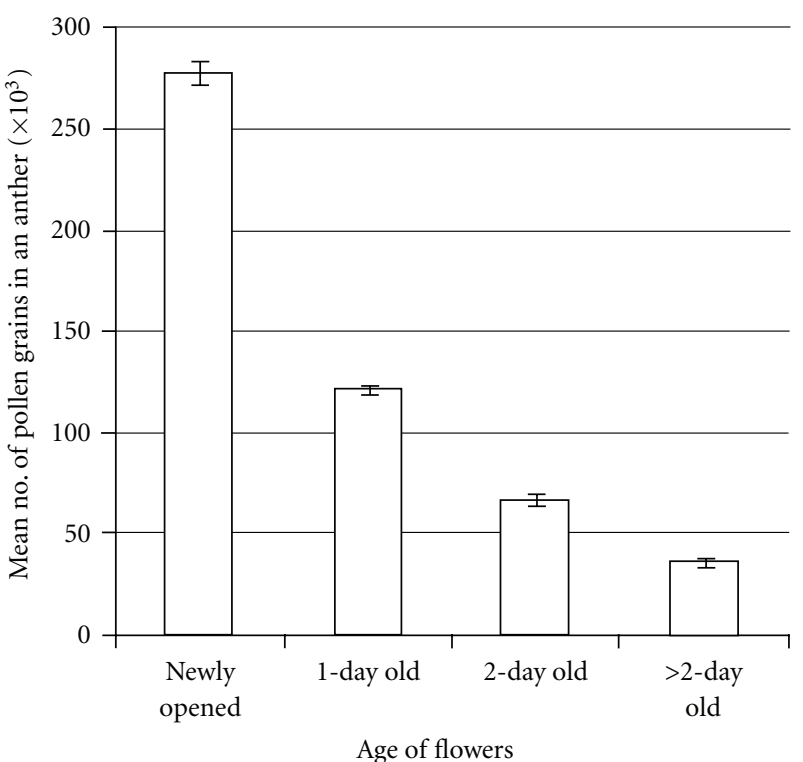

Figure 1: Variation in the mean number of pollen grains in an anther of Solanum violaceum as a function of the age of the flower.

3.1. Number of Pollen Grains in Anthers with Flower Age. Figure 1 shows the variation in the mean number of pollen grains in anthers with the age of the flower. The highest amount of pollen grains was found in new anthers. The lowest amount of pollen was found in anthers more than two days old. The results of the Kruskal-Wallis test were significant $(H=17.97,3$ d.f., $P=0.000)$ indicating that the mean number of pollen grains in anthers was significantly different among the different age categories of flowers.

3.2. Bees Visiting Flowers of S. violaceum. The preliminary survey conducted at Meewatura recorded four species of bees visiting flowers of $S$. violaceum of which, Hoplonomia westwoodi and Patellapis kaluterae (family Halictidae) were the buzzing bees and Trigona iridipennis and Apis dorsata (family Apidae) were the non-buzzing bees.

At the Kegalle site, S. violaceum flowers were visited by four species of buzzing bees namely; Amegilla comberi, Xylocopa tenuiscapa (family Apidae), $H$. westwoodi and $P$. kaluterae (family Halictidae), of which the latter two species were the most common. Xylocopa tenuiscapa was the rarest species and was mostly found hovering above the crop field. Ceratina hieroglyphica, T. iridipennis and A. dorsata (family Apidae) were the non-buzzing bees at this site. The nonbuzzing bees were found collecting pollen spread over the flower petals that released due to the activities of the vibratile pollinators and they were found foraging on stigmae as well.

3.3. Activity Time of Pollen Carrying Bees on Flowers of S. violaceum. The pollen carrying bees were observed to study their activity time in flowers of S. violaceum on five sunny days. Activity time of buzzing and non-buzzing bees that visited S. violaceum flowers is given in Figure 3. 
The first to visit flowers of $S$. violaceum were the buzzing bees and were followed by the honeybees. The starting time of activity between non-buzzing bees and buzzing bees was significantly different $(P$-value $=0.000, T$-value $=4.79, \mathrm{DF}=$ $25)$. However, the end of activity between non-buzzing bees and buzzing bees was not significantly different $(P$-value $=$ $0.162, T$-value $=1.45, \mathrm{DF}=23)$. The non-buzzing bees; A. dorsata, T. iridipennis and C. hieroglyphica were observed mostly after 9.30 a.m. The peak activity period during which most of the bee species were active on flowers in the Kegalle site was from 9.30 a.m. to 11.00 a.m.

3.4. Handling Time of the Two Common Buzzing Bee Species in Flowers at Different Age. Hoplonomia westwoodi (mean body length $=8.49 \mathrm{~mm}$ ) and $P$. kaluterae (mean body length = $6.74 \mathrm{~mm}$ ), of which the former bee is comparatively larger in size, were the most common buzzing bee species in the site at Kegalle. The body length of the two buzzing bee species were also significantly different $(T$-value $=54.44, P$-value $=0.000, \mathrm{DF}=15)$. Figure 2 compares the mean handling time of the two buzzing bee species on newly opened, 1-dayold, 2-day-old and > 2-day-old flowers. The longest handling time of the two bee species was observed at new flowers while the shortest handling time was at flowers $>2$-days-old. There was a significant difference between the age of flower and handling time of $H$. westwoodi $(H=70.85,3$ d.f., $P=0.000)$ and $P$. kaluterae $(H=73.61,3$ d.f., $P=0.000)$.

There was a significant difference between the handling time of $H$. westwoodi and $P$. kaluterae on newly opened flowers $(T$-value $=-7.38, P$-value $=0.000, \mathrm{DF}=35), 1$-dayold flowers $(T$-value $=-5.23, P$-value $=0.000, \mathrm{DF}=33)$, 2 -day-old flowers $(T$-value $=-4.83, P$-value $=0.000, \mathrm{DF}=$ 36 ) and more than 2-day-old flowers $(T$-value $=-2.85, P$ value $=0.009, \mathrm{DF}=35)$ at $95 \%$ confidence interval. Close observations revealed that, $P$. kaluterae vibrates each anther cone of a single flower separately, spending more time at a flower compared to $H$. westwoodi that vibrates all anther cones of a single flowers together at once.

\subsection{Efficiency of Buzz Pollination in Fruit Set and Seed Set of S. violaceum}

3.5.1. Fruit Set. Of the 15 flower bunches that contained about 230 flowers of $S$. violaceum kept open to facilitate bee visits, 95 fruits were formed representing $41.31 \%$ of the total flowers. The highest number of fruits (10 fruits) was obtained from one of the opened bunches which had 18 flowers (55.55\%) while the lowest number of fruits (4 fruits) was obtained from the opened bunch which had 12 flowers (33.33\%).

Of the other 15 flower bunches that contained about 230 flowers of $S$. violaceum kept closed by fine mesh bags to prevent bee visits, only 38 fruits were formed representing $16.52 \%$ of the total flowers. The highest number of fruits (4 fruits) was obtained from the closed bunch which had 18 flowers $(22.22 \%)$ and lowest number of fruits (1 fruit) was from the closed bunch which had 14 flowers (7.14\%).

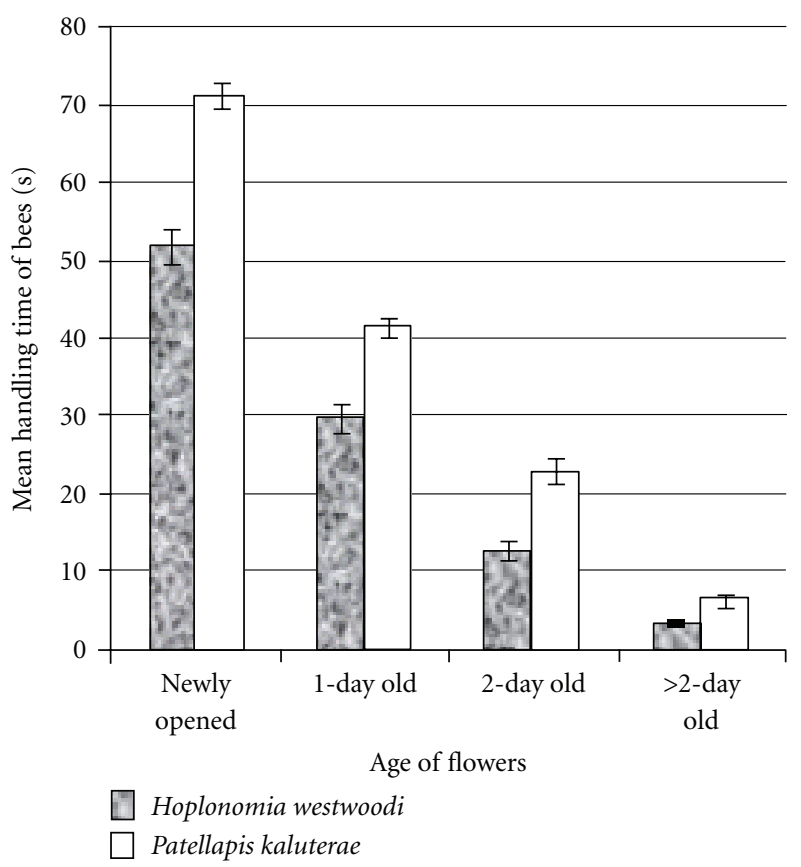

Figure 2: Mean handling time of Hoplonomia westwoodi and Patellapis kaluterae in Solanum violaceum flowers of different age in the site at Kegalle. (Mean temperature $\left({ }^{\circ} \mathrm{C}\right.$ ), rain fall $(\mathrm{mm})$, and relative humidity during the time of observations for the eight days: $30.11 .2009-27.20^{\circ} \mathrm{C}, 0.0 \mathrm{~mm}, 90$; 01.12.2009-26.8 ${ }^{\circ} \mathrm{C}, 0.0 \mathrm{~mm}, 94 ; 02.12 .2009-26.9^{\circ} \mathrm{C}, 0.0 \mathrm{~mm}, 88$; 3.12.2009-27. ${ }^{\circ} \mathrm{C}, 0.0 \mathrm{~mm}, 85 ; 04.12 .2009-26.8^{\circ} \mathrm{C}, 0.00 \mathrm{~mm}, 78$; $05.12 .2009-26.4^{\circ} \mathrm{C}, 0.00 \mathrm{~mm}, 80 ; 06.12 .2009-25.9^{\circ} \mathrm{C}, 0.0 \mathrm{~mm}$, $\left.79 ; 07.12 .2009-26.1^{\circ} \mathrm{C}, 0.0 \mathrm{~mm}, 79\right)$.

Statistical analysis indicated that there is a significant difference between the number of fruits formed from open flowers and bagged flowers $(T$-value $=-7.29, P$-value $=0.000$, $\mathrm{DF}=22$.

3.5.2. Seed Set. The two-Sample $t$-test for number of seeds formed from open flowers versus bagged flowers indicated that there is a significant difference between the number of seeds produced from open flowers and bagged flowers ( $T$ value $=12.06 ; P$-value $=0.000, \mathrm{DF}=108)$. Of the fruits formed from open flower bunches, $96 \%$ of the total number of 248 seeds were germinated. In fruits formed from bagged flower bunches, $92 \%$ of the total number of 208 seeds were germinated. Statistical analysis indicated that the number of germinated seeds produced from the open flowers were significantly different from that of bagged flowers ( $T$-value $=6.34, P$-value $=0.000, \mathrm{DF}=12$ ).

\section{Discussion}

4.1. Bee Visitors of S. violaceum. As floral nectar is absent in flowers of Solanum [18], all the bees visited S. violaceum for pollen. The most common bees visiting $S$. violaceum flowers were buzzing bees belong to the family Halictidae that contains the highest number of bee species recorded for 


\begin{tabular}{|c|c|c|c|c|c|c|c|c|c|c|c|c|c|c|c|}
\hline Day & Bee sp. & $\begin{array}{c}7.30- \\
8.00 \\
\end{array}$ & $\begin{array}{c}8.00- \\
8.30 \\
\end{array}$ & $\begin{array}{c}8.30- \\
9.00\end{array}$ & $\begin{array}{c}9.00- \\
9.30 \\
\end{array}$ & $\begin{array}{l}9.30- \\
10.00\end{array}$ & $\begin{array}{c}10.00- \\
10.30 \\
\end{array}$ & $\begin{array}{c}10.30- \\
11.00\end{array}$ & $\begin{array}{c}11.00- \\
11.30 \\
\end{array}$ & $\begin{array}{c}11.30- \\
12.00\end{array}$ & $\begin{array}{c}12.00- \\
12.30 \\
\end{array}$ & $\begin{array}{c}12.30- \\
1.00 \\
\end{array}$ & $\begin{array}{c}1.00- \\
1.30 \\
\end{array}$ & $\begin{array}{c}1.30- \\
2.00\end{array}$ & $\begin{array}{c}2.00- \\
2.30 \\
\end{array}$ \\
\hline \multirow{7}{*}{ 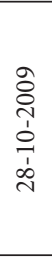 } & H.westwoodi & & & & & & & & & & & & & & \\
\hline & A. comberi & & & & & & & & & & & & & & \\
\hline & P. kaluterae & & & & & & & & & & & & & & \\
\hline & X. tenuiscapa & & & & & & & & & & & & & & \\
\hline & A. dorsata & & & & & & & & & & & & & & \\
\hline & T. iridipennis & & & & & & -1 & & & & & & & & \\
\hline & C. hieroglyphica & & & & & & & ---- & ----- & ----- & & & & & \\
\hline \multirow{7}{*}{ 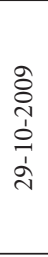 } & H.westwoodi & & & & & & & & & & & & & & \\
\hline & A. comberi & & & & & & & & & & & & & & \\
\hline & P. kaluterae & & & & & & & & & & & & & & \\
\hline & X. tenuiscapa & & & & & & & & & & & & & & \\
\hline & A. dorsata & & & & & & ---- & ----- & ----1 & ----- & ----- & & & & \\
\hline & T. iridipennis & & & & ---- & --1 & ----1 & ---- & ----- & & & & & & \\
\hline & C. hieroglyphica & & & & ---- & ----- & ----- & ---- & ----- & ----- & ---- & & & & \\
\hline \multirow{7}{*}{ 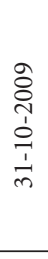 } & H.westwoodi & & & & & 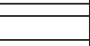 & & & & & & & & & \\
\hline & A. comberi & & & & & & & & & & & & & & \\
\hline & P. kaluterae & & & & & & & & & & & & & & \\
\hline & X. tenuiscapa & & & & & & & & & & & & & & \\
\hline & A. dorsata & & & ---- & ----- & ---- & ----- & ----- & ----- & ----- & & & & & \\
\hline & T. iridipennis & & & & & ----- & ---- & ----- & ----- & & & & & & \\
\hline & C. hieroglyphica & & & & & -- & -- & & 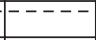 & -- & & & & & \\
\hline \multirow{7}{*}{ 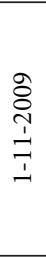 } & H.westwoodi & & & & & & & & & & & & & & \\
\hline & A. comberi & & & & & & & & & & & & & & \\
\hline & P. kaluterae & & & & & & & & & & & & & & \\
\hline & X. tenuiscapa & & & & & & & & & & & & & & \\
\hline & A. dorsata & & & & & ---- & ---- & ----- & ----- & ----- & & & & & \\
\hline & T. iridipennis & & & & & ----- & ---- & ---- & ----- & & & & & & \\
\hline & C. hieroglyphica & & & & & & & & & & & & & & \\
\hline \multirow{7}{*}{ 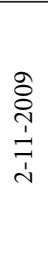 } & H.westwoodi & & & & & & & & & & & & & & \\
\hline & A. comberi & & & & & & & & & & & & & & \\
\hline & P. kaluterae & & & & & & & & & & & & & & \\
\hline & X. tenuiscapa & & & & & & & & & & & & & & \\
\hline & A. dorsata & & & & & & ----- & ----- & $\overline{----}$ & ----- & ---- & ---1 & ----1 & & \\
\hline & T. iridipennis & & & & & & ----- & ----- & & & & & & & \\
\hline & C. hieroglyphica & & & & & & & & & & & & & & \\
\hline
\end{tabular}

Figure 3: Activity time of seven species of bees (Hoplonomia westwoodi, Amegilla comberi, Patellapis kaluterae, Xylocopa tenuiscapa, Apis dorsata, Trigona iridipennis, and Ceratina hieroglyphica; — pollen bees, - - -honeybees) visiting flowers of Solanum violaceum from 7.30 a.m. to 2.30 p.m. during 5 sunny days in the site at Kegalle.

Sri Lanka [19]. The difference in the species composition of bees between the Kegalle site and the Kandy site indicates the site specificity of bee species visiting the same crop in different parts of the country. Hoplonomia, Patellapis, and Amegilla species are ground nesting bees [20] that cannot be reared by providing nesting places as for domesticated honeybees, leafcutter bees, and other stem nesting bees for crop pollination. This finding highlights the importance of conserving this wild bee fauna in an around crop fields even during the off season of crops. The three nonbuzzing bees Apis dorsata, Trigona iridipennis, and Ceratina hieroglyphica may contribute to pollinate the tiny flowers of $S$. violaceum as they were found sometimes on stigmae of flowers. Anderson and Symon [15] report that Trigona species are very abundant on Solanum flowers with $99 \%$ floral fidelity and hence are significant pollinators. A similar study conducted in the Kandy site recorded A. cerana, the most common honeybee in Sri Lanka visiting flowers of $S$. melongena [21]. The absence of this species in S. violaceum flowers needs to be invesigated. An islandwide survey of insects visiting $S$. violaceum would document the different species of buzzing and non-buzzing bees in different parts of the country to reduce the biasness in results of the present study.

The buzzing bees observed during the present study are generalists that visit a wide range of flowers for pollen and nectar [10]. In flowers of S. violaceum, these generalist bees have become specialists to collect pollen, indicating that $S$. violaceum has restricted its pollen availability to a particular group of bees that can vibrate their anther cones to release pollen. The significant difference in the starting time of activity of buzzing and non-buzzing bees indicates the importance of the buzz pollinators to initiate pollen release that benefit the other non-buzzing bees visiting $S$. violaceum. Buzzing bees visited newly opened flowers more frequently than senescent ones with faded white petals and brown colour anthers $[22,23]$ and with no contrast that might provide the long-distance cue to identify the depletion 
of pollen in anthers with flower age $[11,24,25]$. These signals may help the bees to spend their energy only for successful floral visits.

4.2. Age of Flower, Pollen Availability, and Handling Time of Buzz Pollinators. The release of large amounts of pollen during initial vibrations of new flowers by bees [26] decreases the amount of pollen with its age. The depletion in the number of pollen grains per anther with age of the flowers is correlated to the handling time $[8,11,27,28]$ of $H$. westwoodi and P. kaluterae. Harder and Barclay [12] suggested similar finding for Solanum flowers. The decreased handling time of the two buzzing bees, $H$. westwoodi and P. kaluterae, with the age of the flower might be due to the low availability of pollen which is evident from the age-dependant changes in flowers. Buchmann [5] stated an opposite finding to the present study, where the handling time is shorter at new flowers than at older flowers, as bees tend to buzz longer times in flowers with low pollen amounts. This might be possible in systems with low pollen availability, if the emerging of the buzz pollinators is seasonal and also to reduce competition among the buzzing bees active at the same time which is not similar to the present study system.

The body size of $H$. westwoodi and P. kaluteare inversely correlated with their handling time [15]. The difference in handling time between the two species is most likely due to their behavior in vibrating the anther cones, either singly or collectively depending on their body size. This finding is also supported by Buchmann [5] and Shelly and Villalobos [11]. According to Symon [9], only large insects are capable of buzzing and removing pollen from the anthers and function as pollen vectors. The two common bee species recorded during the present study are comparatively smaller bees. However, the largest bee in Sri Lanka, X. tenuiscapa that visited the flowers of $S$. violaceum that are smaller, could not handle the anther cones efficiently.

\subsection{Buzz Pollination for Fruit Set and Seed Set in Solanum} violaceum. The significant difference in fruit set and seed set between the two treatments may be mostly due to bee visits that facilitate removal and transport of pollen in open flowers. Buzzing bees visiting open flowers might have either cross-pollinated, self-pollinated, or might have pollinated by both methods efficiently than the closed flowers that might have self-pollinated in the absence of buzzing bees. The pollen from the cloud due to vibration by bees may directly land on stigma of the same flower facilitating selfpollination. If the bee has pollen on its body collected during previous visits from other plants, it may land on the stigma facilitating cross-pollination. Pollen from anthers of bagged flowers may release due to wind vibrations. Therefore, it seems that $S$. violaceum flowers are using both the biotic and abiotic pollinating agents for its pollination [29-32]. Close observations should be carried out to monitor bee visits to investigate the contribution of cross-pollination by bees to enhance seed set and fruit set versus self-pollination in S. violaceum. Kakizaki [33], Jones and Rosa [34] and Pal and Taller [35] report that Solanum plants grown in cages without bees produced no fruits. Baily [36] and Aizen et al. [37] report that a large number of seeds were produced by cross-pollination by bees compared to artificial pollination which resulted in fewer seeds in S. melongena. Fandino [24] reported that the mean number of seeds obtained from selfpollination was lower than from pollination experiments with bumblebees, showing that buzz pollination is more suitable for reaching a higher seed formation. The significant difference between the number of germinated seeds obtained per fruit produced from bagged flowers and open flowers may be due to bee pollination of open flowers that facilitates cross-pollination. In the presence of bees, germinability of Brassica napus has increased from $83 \%$ to $96 \%$ [38], which is also evident from the present study. The findings of the present study emphasize the importance of natural wild bees in pollinating the local naturalized exotic crops under natural conditions.

\section{Acknowledgments}

The authors are grateful to the Department of Agriculture Engineering for providing access to the Agriculture Research Fields at Meewatura, University of Peradeniya. Constructive comments made by the anonymous reviewers of the paper are gratefully acknowledged.

\section{References}

[1] R. J. Mitchell, R. E. Irwin, R. J. Flanagan, and J. D. Karron, "Ecology and evolution of plant-pollinator interactions," Annals of botany, vol. 103, no. 9, pp. 1355-1363, 2009.

[2] J. E. Cresswell, "Accurate theoretical prediction of pollinatormediated gene dispersal," Ecology, vol. 86, no. 3, pp. 574-578, 2005.

[3] B. Heinrich and P. H. Raven, "Energetics and pollination ecology," Science, vol. 176, pp. 597-602, 1972.

[4] S. L. Buchmann, "Bees use vibration to aid pollen collection from non-poricidal flowers," Journal of the Kansas Entomological Society, vol. 58, no. 3, pp. 517-525, 1985.

[5] S. L. Buchmann, "Buzz pollination in angiosperms," in Handbook of Experimental Pollination Biology, C. E. Jones and R. J. Little, Eds., pp. 73-133, Van Nostrand Reinhold, New York, NY, USA, 1983.

[6] B. M. H. Larson and S. C. H. Barrett, "The pollination ecology of buzz-pollinated Rhexia virginica (Melastomataceae)," American Journal of Botany, vol. 86, no. 4, pp. 502-511, 1999.

[7] C. E. B. Proenca, "Buzz pollination-older and more widespread than we think," Journal of Tropical Ecology, vol. 8, no. 1, pp. 115-120, 1992.

[8] S. L. Buchmann and J. H. Cane, "Bees assess pollen returns while sonicating Solanum flowers," Oecologia, vol. 81, no. 3, pp. 289-294, 1989.

[9] D. E. Symon, "Fruit diversity and dispersal in Solanum in Australia," Journal of the Adelaide Botanical Garden, vol. 1, pp. 321-331, 1979.

[10] W. A. I. P. Karunaratne, J. P. Edirisinghe, and C. V. S. Gunatilleke, "Floral relationships of bees in selected areas of Sri Lanka," Ceylon Journal of Science, vol. 34, pp. 27-45, 2005.

[11] T. E. Shelly and E. Villalobos, "Buzzing bees on Solanum (Solanaceae): floral choice and handling time track pollen 
availability," Florida Entomologist, vol. 83, no. 2, pp. 180-187, 2000.

[12] L. D. Harder and R. M. R. Barclay, "The functional significance of poricidal anthers and buzz pollination: controlled pollen removal from Dodecatheon," Functional Ecology, vol. 8, no. 4, pp. 509-517, 1994.

[13] E. L. D. S. Bezerra and I. C. Machado, "Floral biology and pollination system of Solanum stramonifolium Jacq. (Solanaceae) in an Atlantic Forest remnant in Pernambuco," Acta Botanica Brasilica, vol. 17, no. 2, pp. 247-257, 2003.

[14] T. H. Roulston, J. H. Cane, and S. L. Buchmann, "What governs protein content of pollen: pollinator preferences, pollenpistil interactions, or phylogeny?” Ecological Monographs, vol. 70, no. 4, pp. 617-643, 2000.

[15] J. Anderson and D. Symon, "Insect foragers on Solanum flowers in Australia," Annals of the Missouri Botanical Garden, vol. 75, no. 3, pp. 842-852, 1988.

[16] K. A. W. Bowers, "The pollination ecology of Solanum rostratum (Solanaceae)," American Journal of Botany, vol. 62, no. 6, pp. 633-638, 1975.

[17] W. A. I. P. Karunaratne and J. P. Edirisinghe, "Key to the identification of common bees of Sri Lanka," Journal of the National Science Foundation, vol. 36, no. 1, pp. 75-97, 2008.

[18] G. J. Anderson and D. E. Symon, "Extrafloral nectarines in Solanum," Biotropica, vol. 17, pp. 40-45, 1985.

[19] W. A. I. P. Karunaratne, J. P. Edirisinghe, and A. Pauly, An Updated Checklist of Bees of Sri Lanka with New Records, MAB Handbook and Occasional Paper Series no. 23, National Science Foundation, 2005.

[20] C. D. Michener, Bees of the World, Johns Hopkin University Press, Baltimore, Md, USA, 2000.

[21] U. J. M. S. R. Jayasinghe and W. A. I. P. Karunaratne, "Buzz pollination of Solanum melongena by bees," Proceedings of the Peradeniya University Research Sessions, vol. 14, pp. 290-292, 2009.

[22] M. R. Weiss, "Floral colour changes as cues for pollinators," Nature, vol. 354, no. 6350, pp. 227-229, 1991.

[23] M. R. Weiss, "Floral color change: a widespread functional convergence," American Journal of Botany, vol. 82, no. 2, pp. 167-185, 1995.

[24] M. T. A. Fandino, Management of Bombus Atratus Bumblebees to Pollinate Lulo (Solanum quitoense L), a Native Fruit from the Andes of Colombia, Ecology and Development Series no. 50, 2007, edited by P. L .G. Vlek, M. Denich, C. Martius, C. Rodgers, and N. van de Giesen.

[25] K. Lunau, "Colour saturation triggers innate reactions to flower signals: flower dummy experiments with bumblebees," Journal of Comparative Physiology, vol. 166, no. 6, pp. 827-834, 1990.

[26] M. J. King and S. L. Buchmann, "Sonication dispensing of pollen from Solanum laciniatum flowers," Functional Ecology, vol. 10, no. 4, pp. 449-456, 1996.

[27] L. D. Harder, "Behavioral responses by bumble bees to variation in pollen availability," Oecologia, vol. 85, no. 1, pp. 41-47, 1990.

[28] O. Pellmyr, "Bumble bees (Hymenoptera: Apidae) assess pollen availability in Anemonopsis macrophylla (Ranunculaceae) through floral shape," Annals of the Entomological Society of America, vol. 81, no. 5, pp. 792-797, 1988.

[29] D. E. Adams, W. E. Perkins, and J. R. Estes, "Pollination systems in Paspalum dilatatum Poir. (Poaceae): an example of insect pollination in a temperate grass," American Journal of Botany, vol. 68, pp. 389-394, 1981.
[30] A. B. Anderson, W. L. Overal, and A. Henderson, "Pollination ecology of a forest-dominant palm (Orbignya phalerata Mart.) in northern Brazil," Biotropica, vol. 20, no. 3, pp. 192-205, 1988.

[31] J. H. Cane and J. A. Payne, "Regional, annual, and seasonal variation in pollinator guilds: intrinsic traits of bees (Hymenoptera: Apoidea) underlie their patterns of abundance at Vaccinium ashei (Ericaceae)," Annals of the Entomological Society of America, vol. 86, pp. 577-588, 1993.

[32] S. S. Renner and J. P. Feil, "Pollinators of tropical dioecious angiosperms," American Journal of Botany, vol. 80, no. 9, pp. 1100-1107, 1993.

[33] Y. Kakizaki, "The flowering habit and natural crossing in the egg-plant," Japan Journal, vol. 3, pp. 29-38, 1924.

[34] H. A. Jones and J. T. Rosa, Truck Crop Plants, McGraw-Hill, New York, NY, USA, 1928.

[35] G. Pal and M. Taller, "Effects of pollination methods on fertilization in egg plant (Solanum melongena)," Acta Agronomica Academiae Scientiarum Hungariae, vol. 18, pp. 307-315, 1969.

[36] L. H. Bailey, Experiences with egg plants, N.Y. (Ithaka) Agriculture Exports Statistics Bull 26, 1891.

[37] M. A. Aizen, L. Ashworth, and L. Galetto, "Reproductive success in fragmented habitats: do compatibility systems and pollination specialization matter?" Journal of Vegetation Science, vol. 13, no. 6, pp. 885-892, 2002.

[38] P. G. Kevan and D. Eisikowitch, "The effects of insect pollination on canola (Brassica napus L. cv. O.A.C. Triton) seed germination," Euphytica, vol. 45, no. 1, pp. 39-41, 1990. 

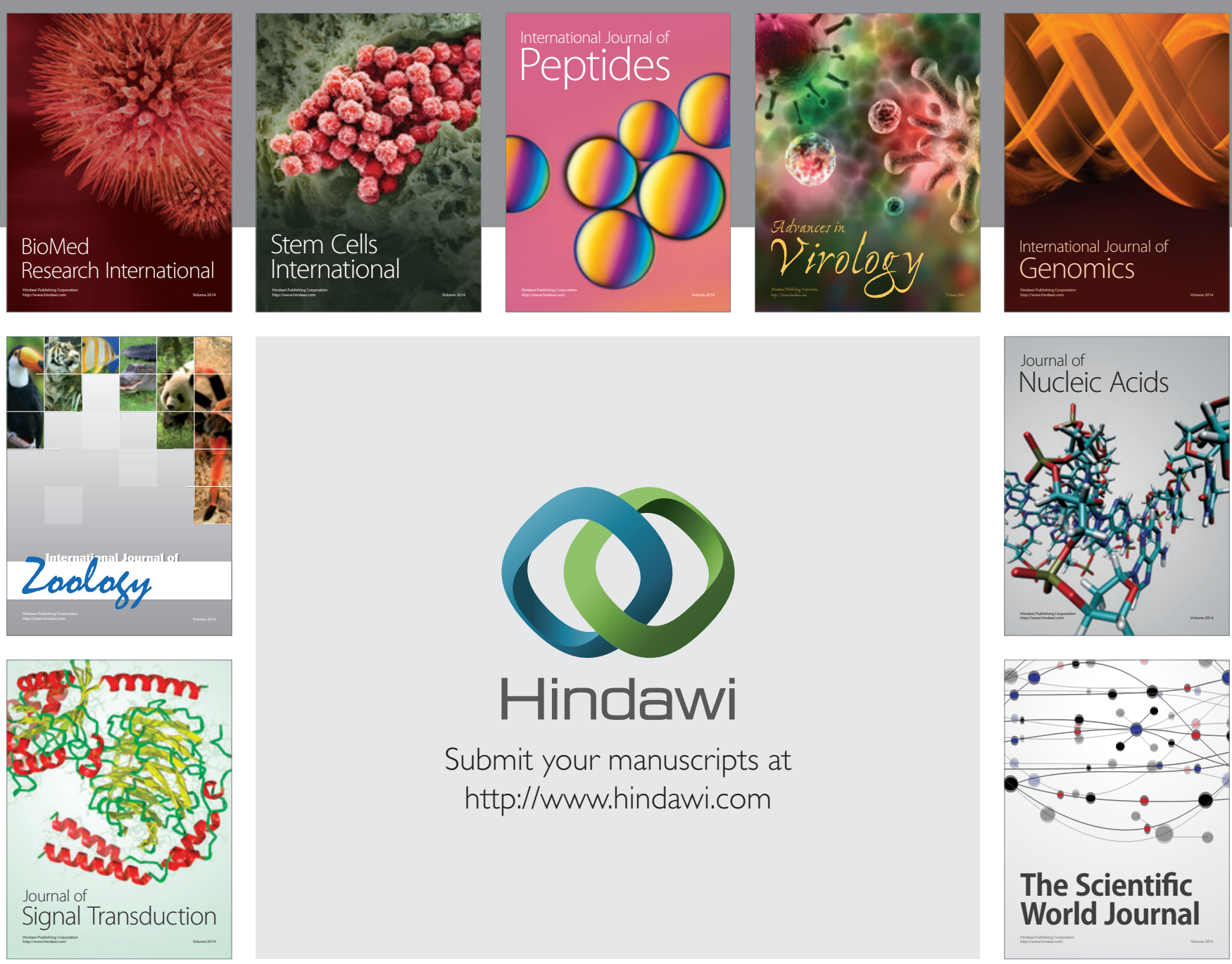

Submit your manuscripts at

http://www.hindawi.com
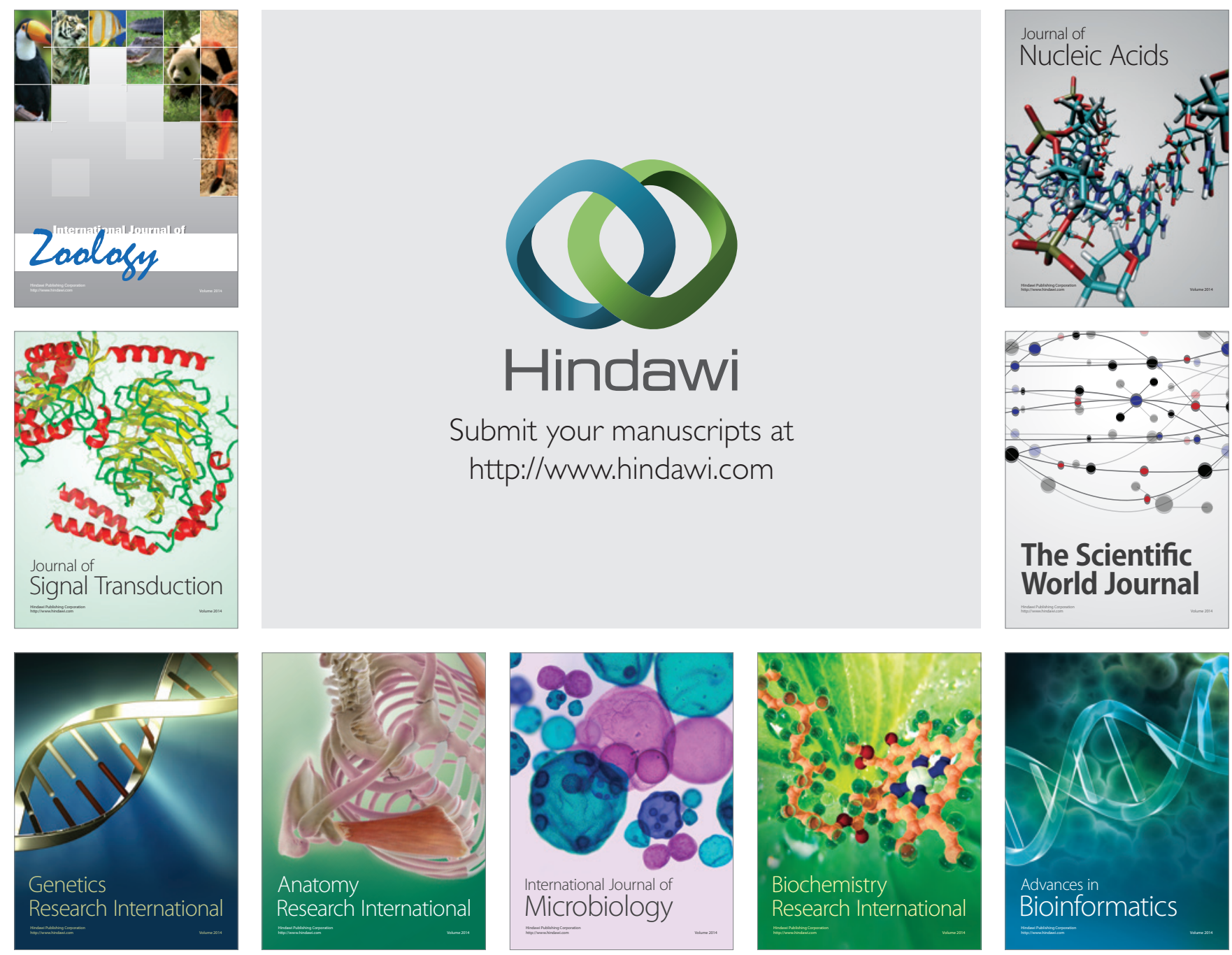

The Scientific World Journal
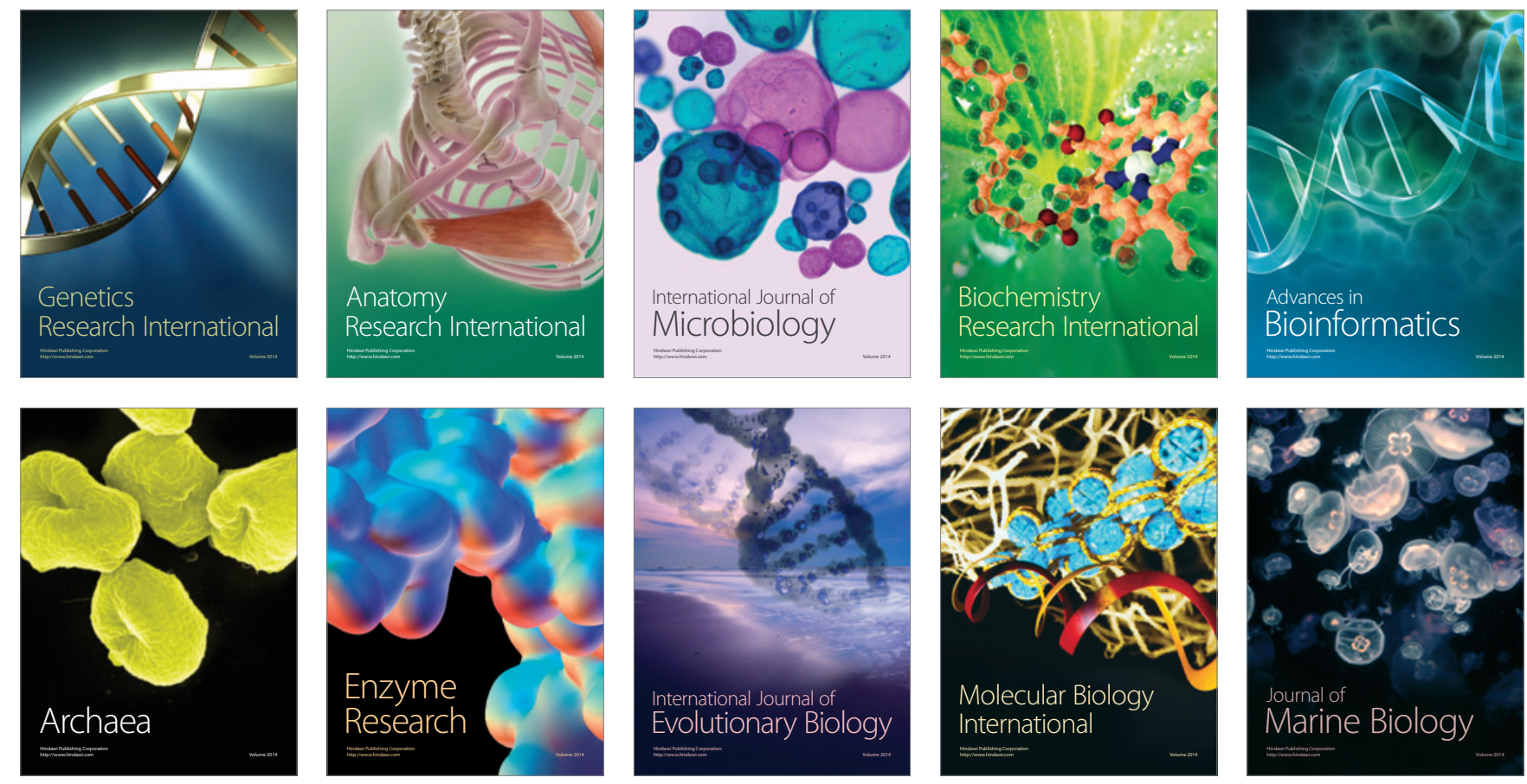